\author{
Marquette University \\ e-Publications@Marquette
}

\title{
Bond-slip Behavior of Fiber-reinforced Polymer/concrete Interface in Single Shear Pull-out and Beam Tests
}

Tayyebeh Mohammadi

Marquette University

Baolin Wan

Marquette University, baolin.wan@marquette.edu

Kent A. Harries

University of South Carolina - Columbia

Follow this and additional works at: https://epublications.marquette.edu/civengin_fac

Part of the Civil Engineering Commons, and the Structural Materials Commons

\section{Recommended Citation}

Mohammadi, Tayyebeh; Wan, Baolin; and Harries, Kent A., "Bond-slip Behavior of Fiber-reinforced Polymer/concrete Interface in Single Shear Pull-out and Beam Tests" (2016). Civil and Environmental Engineering Faculty Research and Publications. 134.

https://epublications.marquette.edu/civengin_fac/134 


\title{
Bond-slip Behavior of Fiber- Reinforced Polymer/Concrete Interface in Single Shear Pull-Out and Beam Tests
}

\author{
Tayyebeh Mohammadi \\ Precast Engineering Company, \\ Brookfield, WI \\ Baolin Wan \\ Department of Civil, Construction, and Environmental \\ Engineering, \\ Marquette University, \\ Milwaukee, WI \\ Kent A. Harries \\ Department of Civil and Environmental Engineering, \\ University of Pittsburgh, \\ Pittsburgh, PA
}




\begin{abstract}
It has been assumed that the fiber-reinforced polymer/concrete interface is subjected to in-plane shear condition when intermediate crack debonding failure occurs. Therefore, the single shear pull-out test results are often used to predict the intermediate crack debonding failure in beams. In this study, the behavior of fiber-reinforced polymer-strengthened concrete beams and single shear pull-out specimens were studied experimentally and numerically. The bond-slip behavior of the fiber-reinforced polymer/concrete interface was obtained by single shear pull-out and beam tests. In all beam specimens, a concrete wedge located at the edge of the notch detached with the fiber-reinforced polymer debonding failure. This phenomenon shows that the initiation of debonding is due to a diagonal crack formation close to the major flexural/shear crack inside the concrete. The diagonal crack formation is due to a local moment at the tip of the notch. This causes the different stress state and slip of the fiber-reinforced polymer/concrete interface of beam specimens from that of the pull-out specimens. It is found that the bond-slip relation obtained from the pull-out test does not represent the bond-slip relation of the fiber-reinforced polymer/concrete interface in the fiber-reinforced polymer-strengthened concrete beams, and it cannot be directly used for predicting the load capacity of the fiber-reinforced polymerstrengthened concrete beams.
\end{abstract}

Keywords Fiber-reinforced polymer/concrete interface, bond, intermediate crack debonding, pull-out test, fracture energy, finite element

\title{
Introduction
}

In civil infrastructure applications, fiber-reinforced polymer (FRP) composite materials have been mainly used for repair or retrofit of concrete structures. When used for these purposes, FRP is usually bonded to the exterior surface or mounted inside the cover concrete of the repaired member. In this type of application, debonding along the $\mathrm{FRP} /$ concrete interface is a principal failure limit state.

When a concrete beam is strengthened with bonded FRP composite materials, FRP debonding along the FRP/concrete interface can be categorized into two main failure modes ${ }^{1}$ as shown in Figure 1 . The first failure mode is plate-end (PE) debonding (Figure 1(a)) which initiates at the ends of the FRP plate and propagates in the direction of increasing moment. Many studies have been carried out to investigate and predict this type of debonding failure mode. $\underline{2}-4$ End wrapping and mechanical anchorage have been found to be efficient methods of mitigating the PE debonding failure in FRP repaired or retrofitted

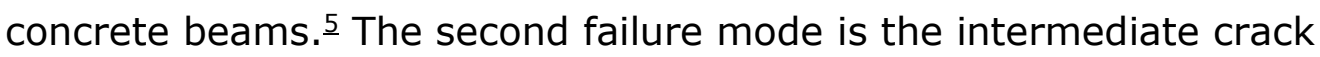
induced debonding (IC debonding) which initiates at a flexural/shear 
crack (intermediate crack) in the concrete within the shear span and propagates toward the plate end in the direction of decreasing moment as shown schematically in Figure 1b. This type of FRP debonding failure, unlike PE debonding, is difficult to prevent. Therefore, it must be explicitly taken into consideration in the design process and addressed as a limit state.

(a)

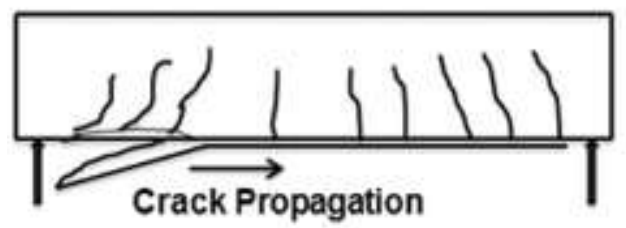

(b) Intermediate Crack

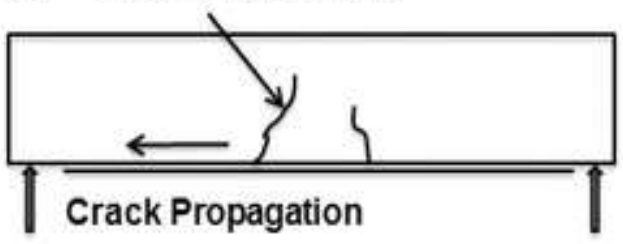

Figure 1. FRP debonding failure: (a) PE debonding and (b) IC debonding.

There are no universally accepted standards for determining bond capacity between FRP and concrete. Normally, the bond between FRP and concrete is tested by applying shear stress to the FRP/concrete interface of a FRP bonded concrete specimen. According to Chen and Teng $\underline{6}$ and Chen et al., ${ }^{7}$ general test methods include double shear pull-out tests, $\underline{\underline{8}-\underline{11}}$ single shear pull-out tests, $\underline{12}-\underline{16}$ and beam tests. $\underline{17}-\underline{19}$ These test methods are presented in Figure 2(a) through (c), respectively. There are a number of variations in the beam tests as summarized by Harries et al. $\underline{20}$ Besides of the test methods applying shear stresses, normal stresses, $\underline{21}-\underline{23}$ and mixed normal and shear stresses $\underline{24} \underline{\underline{25}}$ are also applied to the FRP/concrete interface to evaluate the bond capacity between FRP and concrete. 
(a)

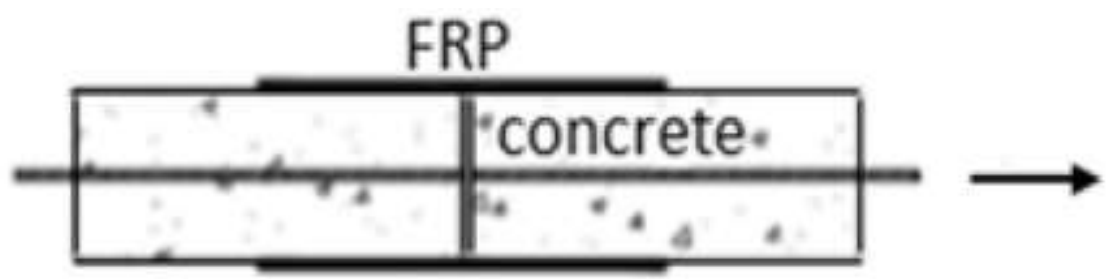

(b)

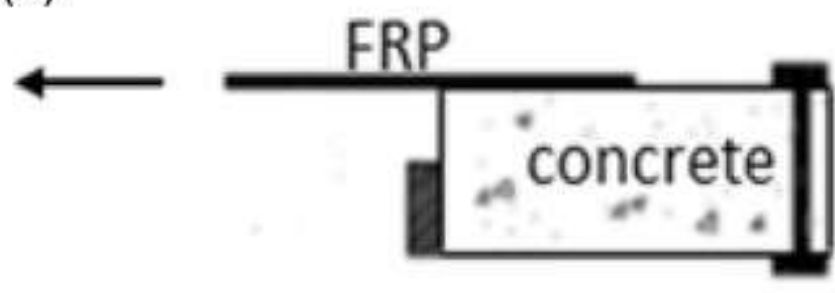

(c)

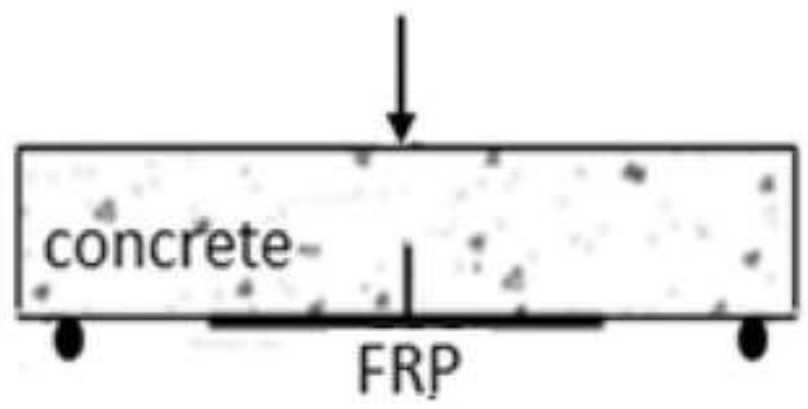

Figure 2. FRP/concrete bond test methods: (a) double pull-out test, (b) single pullout test, and (c) beam test.

In the single shear pull-out test, an in-plane shear stress is applied to the FRP/concrete interface by applying a uniaxial tension load in the plane of the FRP, in the strong or longitudinal direction of the FRP fiber orientation. The tensile strain gradient in the FRP (representing the shear strain along the interface) is recorded and used to determine the bond-slip relation. A typical bond-slip curve is shown in Figure 3 . The area under the bond-slip curve is defined as the mode II fracture energy, $G_{\mathrm{fII}}$, which is a property of the FRPconcrete system. Such a relationship is often used for nonlinear fracture mechanics or cohesive crack models in numerical analyses to predict FRP debonding from a concrete substrate. The single-shear pull-out test is also used to test the bond behavior between other types of innovative composites, such as steel stranded wire mesh and polymer mortar (SMPM) and concrete. $\underline{26}$ 


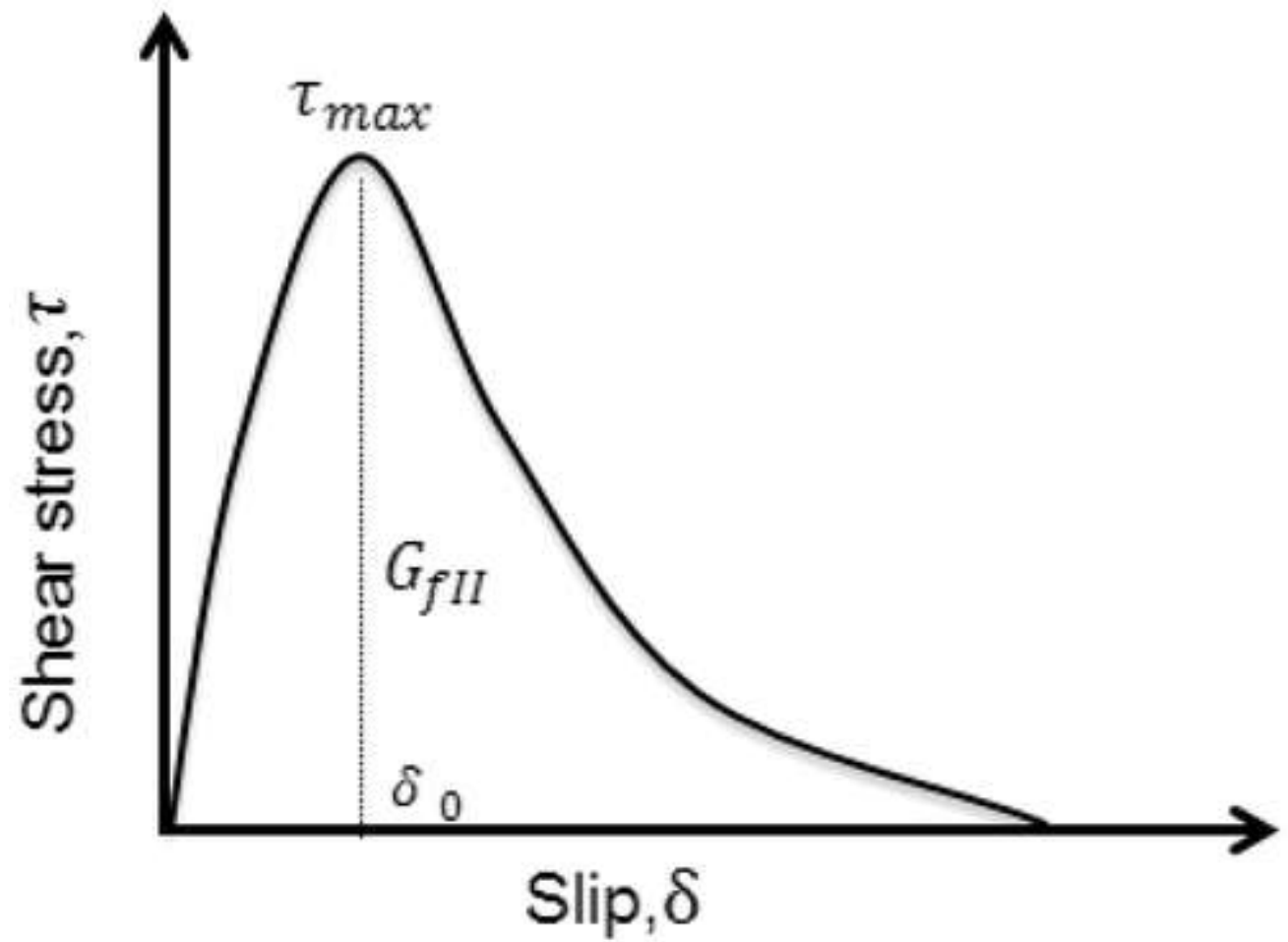

Figure 3. Typical bond-slip curve of a FRP/concrete interface.

It has been concluded from the available literature that using the results of single-shear pull-out test for the calculation of bond-slip relationship of the FRP/concrete interface results in large irregular differences among the bond-slip curves along the bonded length. 27,28 This large scatter of the bond-slip behavior may be due to local FRP composites defects in the application of strengthening systems in-situ such as wrinkles and scratches, $\underline{29}, \underline{30}$ and/or possible heterogeneity of the concrete substrate. Mohammadi et al. $\frac{31}{1}$ showed a significant variation in the interface stiffness using the statistical Brownian motion in a stochastic method that may cause the variation in the $\mathrm{FRP} /$ concrete interface behavior.

Typically, it is assumed that the FRP/concrete interface in IC debonding is subjected to a pure Mode II loading (in-plane shear) condition. Therefore, the single shear pull-out test results are commonly used to predict the IC debonding failure in beams. However, there is no systematic study to validate if the shear test results can be directly used to predict the debonding failure of FRP-strengthened concrete beams. D'Antino and Pellegrino $\underline{32}$ assessed twenty analytical models for the evaluation of the FRP-concrete bond strength found in 
literature, which are mainly calibrated with single and double shear tests. It is found that those models are very inaccurate to predict the bond strength for full-scale bending tests. In this study, the behavior of FRP-strengthened concrete beams and comparable single shear pull-out specimens were studied experimentally and numerically to verify the application of the single shear pull-out test results in strengthened beam design. In order to achieve this objective, the single shear pull-out test was conducted to experimentally establish the bond-slip relationship of the FRP/concrete interface. Corresponding beam specimens were tested to investigate the FRP debonding behavior in the FRP bonded concrete beams. The experimental results were then used to validate finite element (FE) models of the specimens. The FRP/concrete interface stresses in both types of tests, which were found in the FE models, were compared to determine whether the single shear pull-out test results could be used directly to predict the IC debonding failure in FRP-strengthened concrete beams.

\section{Experimental Methods}

Five single shear pull-out specimens (CS1-CS5) and six beam specimens (CMCO-1 to CMC0-6) were tested in the experimental program. Since the main purpose of carrying out the pull-out test in this study was to compare the bond-slip behavior of the pull-out specimens to the bond-slip behavior of the FRP-strengthened beam specimens, the pull-out specimens were made to represent one half of the beam specimens both in terms of dimensions and boundary conditions. The beam test specimens and the pull-out specimens are shown schematically in Figure 4 . As shown in the figure, the length of the concrete block and the FRP plate of the pull-out specimen represent one half of the beam specimen. The cross section of the concrete substrate and FRP width were also same in both specimens. In the beam specimens, a half-depth saw-cut notch was located at mid-span to simulate a pre-existing flexural crack. A recent study 33 shows that the boundary condition of the concrete block has a significant effect on the bond-slip behavior in single shear pull-out tests. To mimic the same boundary conditions of beam specimens in the pull-out specimens, the concrete block was positioned on a rigid frame with two steel reaction elements as shown in Figure 4(b). 
Element $A$ in Figure 4(b) provides the horizontal reactions to simulate the un-cracked part of the beam at the top of the notch, and element $B$ provides the vertical reactions to simulate the support forces in the beam specimens. A 25-mm horizontal precrack (unbonded FRP length) between FRP and concrete was provided in the single shear pull-out specimens and only at one side of the notch in the beam specimens. The bonding length of FRP plate was $406 \mathrm{~mm}$, which is larger than the effective length (192 $\mathrm{mm}$ calculated by using the method recommended by $\mathrm{FIB}^{34}$ ).
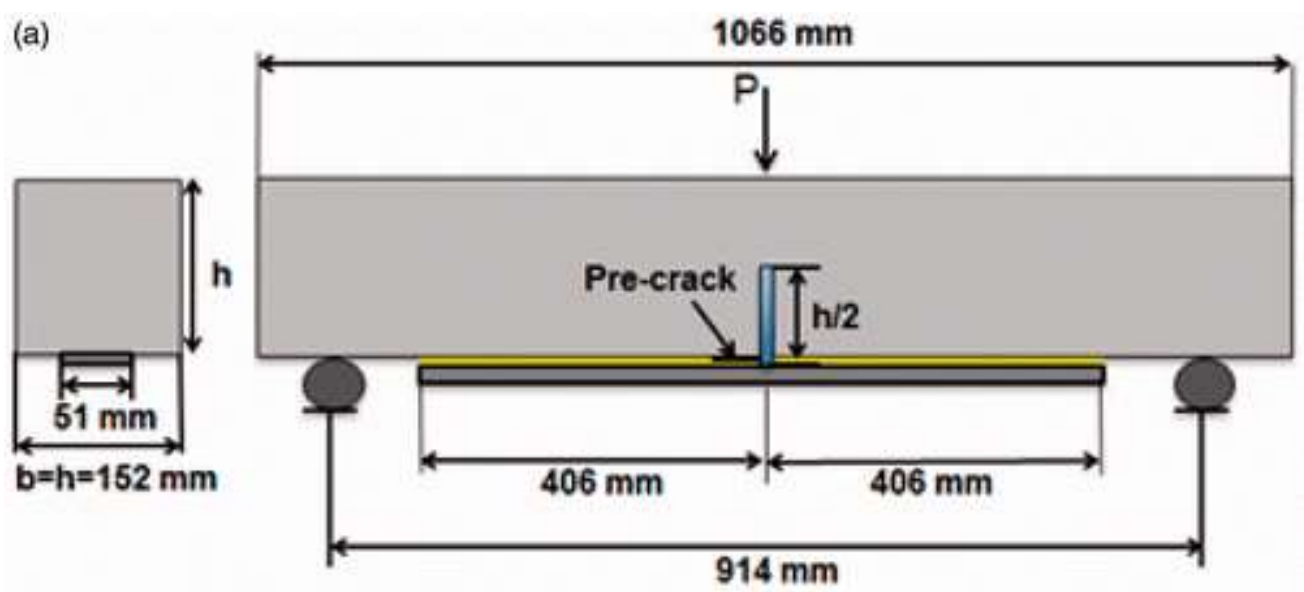

(b)

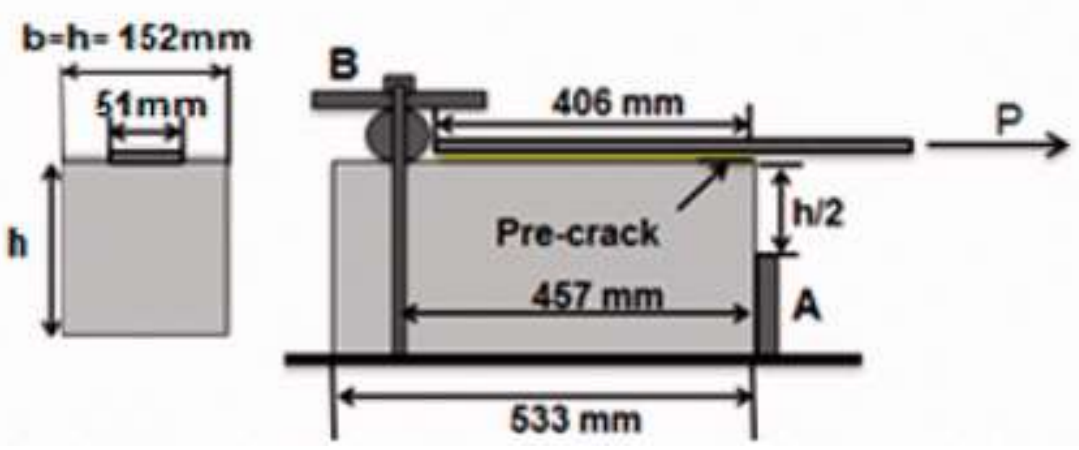

Figure 4. Experimental specimens: (a) beam specimens and (b) single shear pull-out specimens.

\section{Material Properties}

Although placed at different times, the concrete mix design was intended to be the same for both beam and single shear pull-out specimens. The 28-day compressive strength of the beams and pullout specimens were 30.4 and $32.9 \mathrm{MPa}$, respectively. The tensile strength of the beam specimens was determined from split cylinder

Journal of Reinforced Plastics and Composites, Vol 35, No. 5 (March 2016): pg. 375-386. DOI. This article is (C) SAGE Publications and permission has been granted for this version to appear in e-Publications@Marquette. SAGE Publications does not grant permission for this article to be further copied/distributed or hosted elsewhere without the express permission from SAGE Publications. 
tests to be $3.2 \mathrm{MPa}$ (a comparable test was not conducted on the concrete for the pull-out specimens). Both specimens used a $51 \mathrm{~mm} \times 1.5 \mathrm{~mm}$ preformed CFRP laminate strip having manufacturerreported tensile modulus, ultimate tensile strength, and longitudinal Poisson's ratio of $155 \mathrm{GPa}, 2800 \mathrm{MPa}$, and 0.25 , respectively. The $\sim 1-$ $\mathrm{mm}$ thick epoxy adhesive used for the beam specimens had manufacturer-reported tensile modulus, ultimate tensile strength, and Poisson's ratio of $4.48 \mathrm{GPa}, 24.8 \mathrm{MPa}$, and 0.3 , respectively. The $\sim 1-\mathrm{mm}$ thick epoxy adhesive used for the pull-out specimens had manufacturer-reported tensile modulus, ultimate tensile strength, and Poisson's ratio of $1.2 \mathrm{GPa}, 22.7 \mathrm{MPa}$, and 0.3 , respectively.

\section{Beam Test}

Six beam specimens ( $\mathrm{CMCO}-1$ to $\mathrm{CMC0}-6$ ) were tested to study the behavior of IC debonding failure when the major flexural/shear crack is at mid-span of the beam. The tests were conducted under displacement control. During the beam test, flexural load, axial strains in the FRP plate at different locations, and vertical deflection at the top of the notch were recorded. FRP axial strains were measured using electrical resistance strain gauges on the FRP surface. The first strain gauge was applied at the FRP plate surface at the location of the precrack tip and additional strain gauges were attached to the FRP plate surface along its centerline at intervals of $25 \mathrm{~mm}$. An external LVDT bracket was affixed to the beam at its mid-depth in order to measure the vertical deformation at the top of the notch correcting for any support settlement. $\underline{35}$

The IC debonding failure processes were the same in all beam specimens and included:

1. Flexural cracking initiated at the top of the notch (Figure 5(a)).

2. A diagonal flexural/shear crack started close to the notch, about $25 \mathrm{~mm}$ from the notch (Figure 5(b)) at one or other side of the notch, or occasionally both sides.

3. FRP debonding along the FRP/concrete interface initiated at the tip of the diagonal crack and propagated toward the support (Figure 5(c)). 
4. Sudden, essentially instantaneous failure steps included: the diagonal crack merging with the notch, the crack at the top of the notch propagating to the loading point, and FRP debonding continuing to the end of the FRP plate (Figure 5(d)).
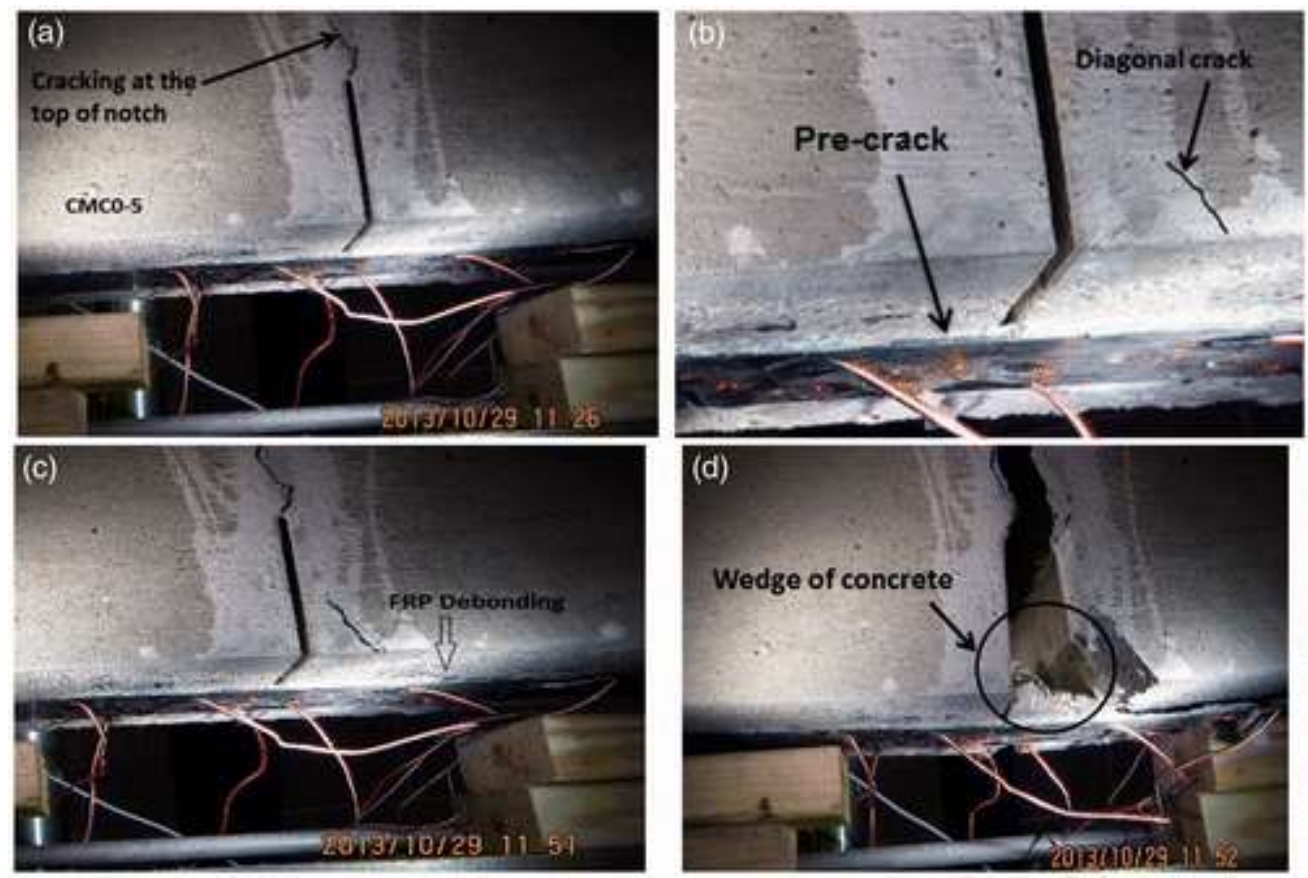

Figure 5. IC debonding failure processes of beam $\mathrm{CMCO}-5$.

In all specimens, there was a wedge of concrete attached to the FRP plate (Figure $5(\mathrm{~d})$ ) that shows diagonal cracking inside the concrete. In all cases, the debonding cracking did not start at the tip of the precrack. Instead, it started at the tip of the diagonal crack to either side of the notch. Therefore, the applied precrack did not work as the initiation point of the FRP debonding and it did not control to which side of the notch FRP debonding would occur.

\section{Single Shear Pull-Out Test}

Five specimens were used for the single shear pull-out test (CS1-CS5). During the test, the applied load, FRP axial strain and the slip between FRP and concrete at the tip of precrack were recorded. The FRP strains were measured using electrical resistance strain gauges attached to the FRP plate surface along its centerline at intervals of $25 \mathrm{~mm}$. A digital dial gauge was used to measure the 
NOT THE PUBLISHED VERSION; this is the author's final, peer-reviewed manuscript. The published version may be accessed by following the link in the citation at the bottom of the page.

relative slip between the concrete and FRP at the precrack tip as shown in Figure 6.

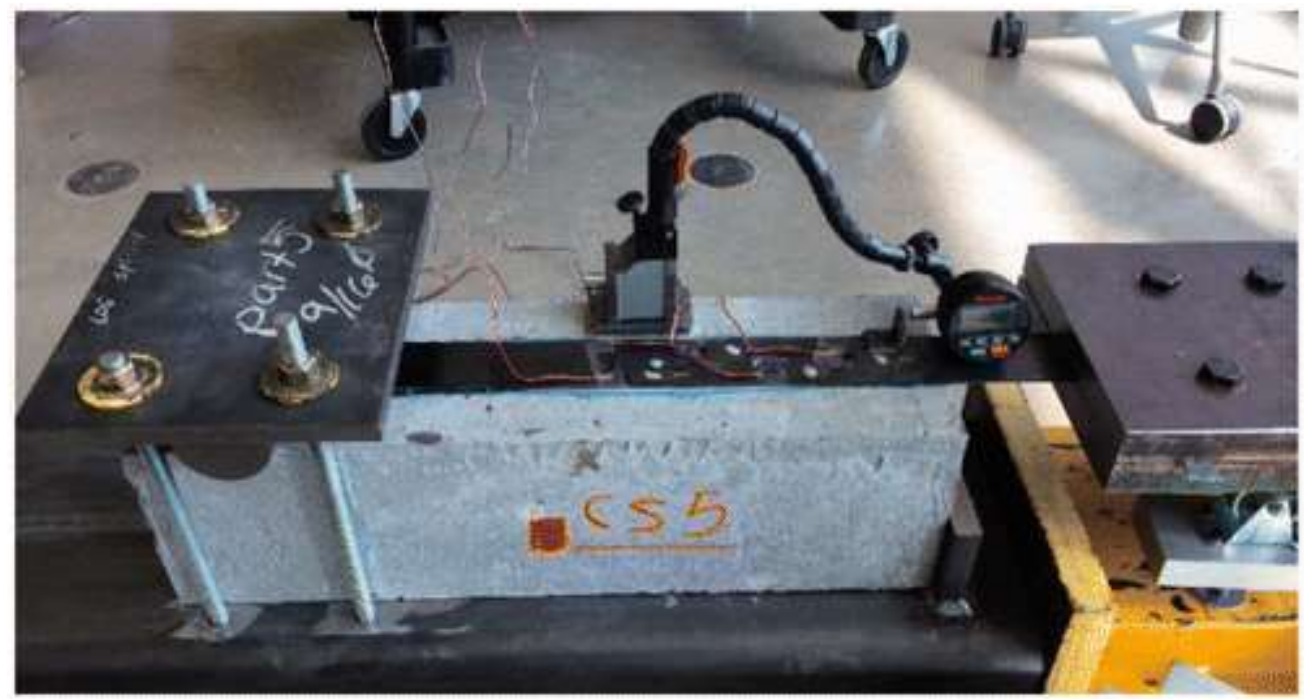

Figure 6. Application of digital dial gauge to obtain the relative slip at the precrack tip.

Figure 7 shows the FRP debonding failure in specimen CS5, which is typical for the single-shear pull-out tests. The debonding initiated at the tip of the precrack and propagated along the FRP plate to the end of the specimen. The failure plane was in the concrete a few millimeters (1-2 mm) away from the FRP/concrete interface.

Journal of Reinforced Plastics and Composites, Vol 35, No. 5 (March 2016): pg. 375-386. DOI. This article is (C) SAGE Publications and permission has been granted for this version to appear in e-Publications@Marquette. SAGE Publications does not grant permission for this article to be further copied/distributed or hosted elsewhere without the express permission from SAGE Publications. 


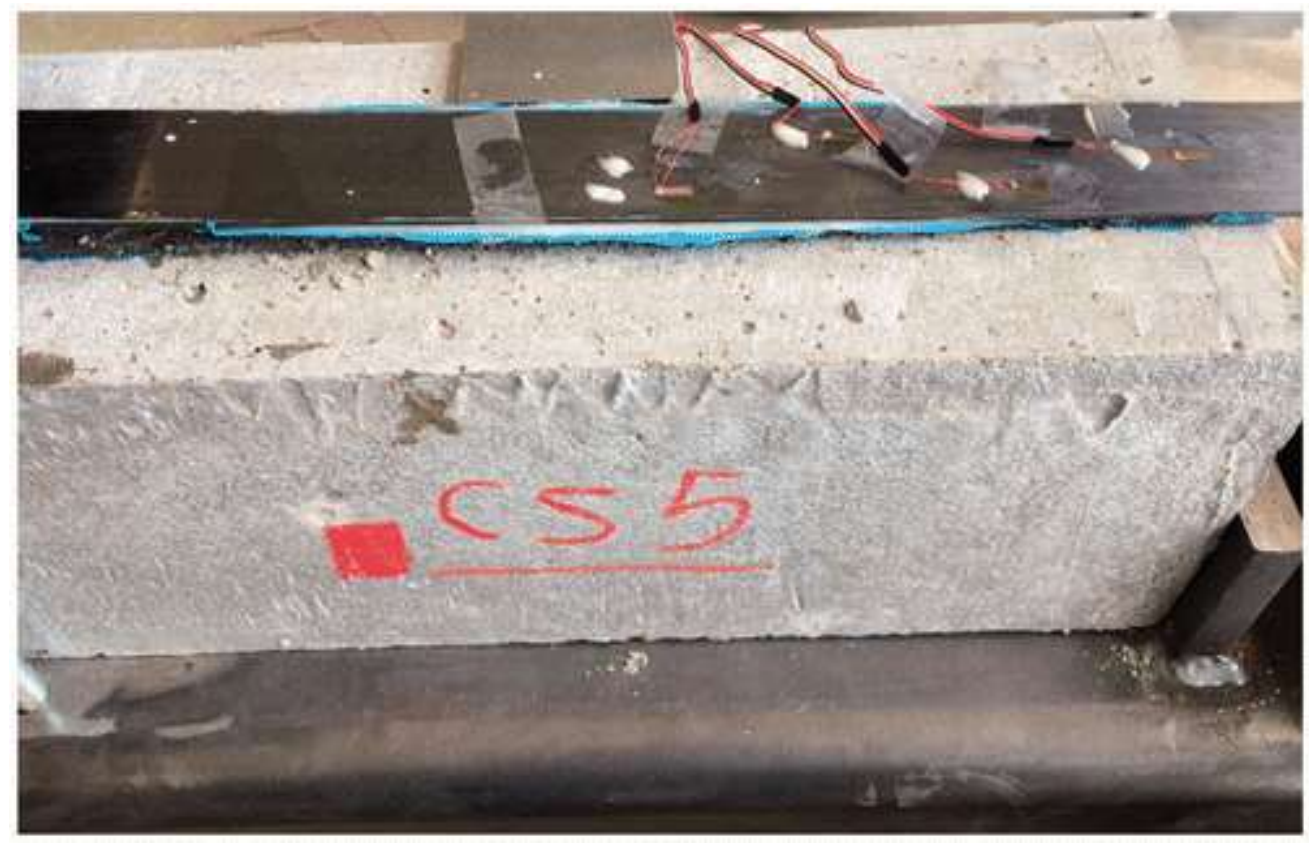

Figure 7. FRP debonding failure of pull-out specimen CS5.

\section{Experimental Bond-Slip Relationship}

In order to obtain the local bond stress-slip relationships of FRP/concrete interfaces from the conducted tests, the measured FRP axial strain data were applied in the following equations $27: \tau_{i}=$

$$
\begin{gathered}
\frac{t_{f} E_{f}}{\Delta x}\left(\varepsilon_{i}-\varepsilon_{i-1}\right) \\
\delta_{i}=\frac{\Delta x}{2}\left(\varepsilon_{0}+2 \sum_{j=1}^{i-1} \varepsilon_{j}+\varepsilon_{i}\right)
\end{gathered}
$$

where $\tau_{i}$ is the average interfacial bond stress in the increment $\mathrm{i}$ having length $\Delta x$ between strain gage data $\varepsilon_{i}$ and $\varepsilon_{i-1}$ representing the $i$ th and $(i-1)$ th gauges arranged along the FRP plate; $E_{f}$ and $t_{f}$ are the elastic modulus and thickness of the FRP plate, respectively; $\delta_{i}$ is the local slip between the FRP plate and concrete at the section i; $\varepsilon_{0}$ is the strain in the FRP plate at the free end of bonded area; and $\varepsilon_{j}$ is the strain value of the $j$ th gauge. Figure 8 shows a representative bondslip curve of the beam test (specimen $\mathrm{CMC0}-6$ ) and the single shear pull-out test (specimen CS5) for comparison. 


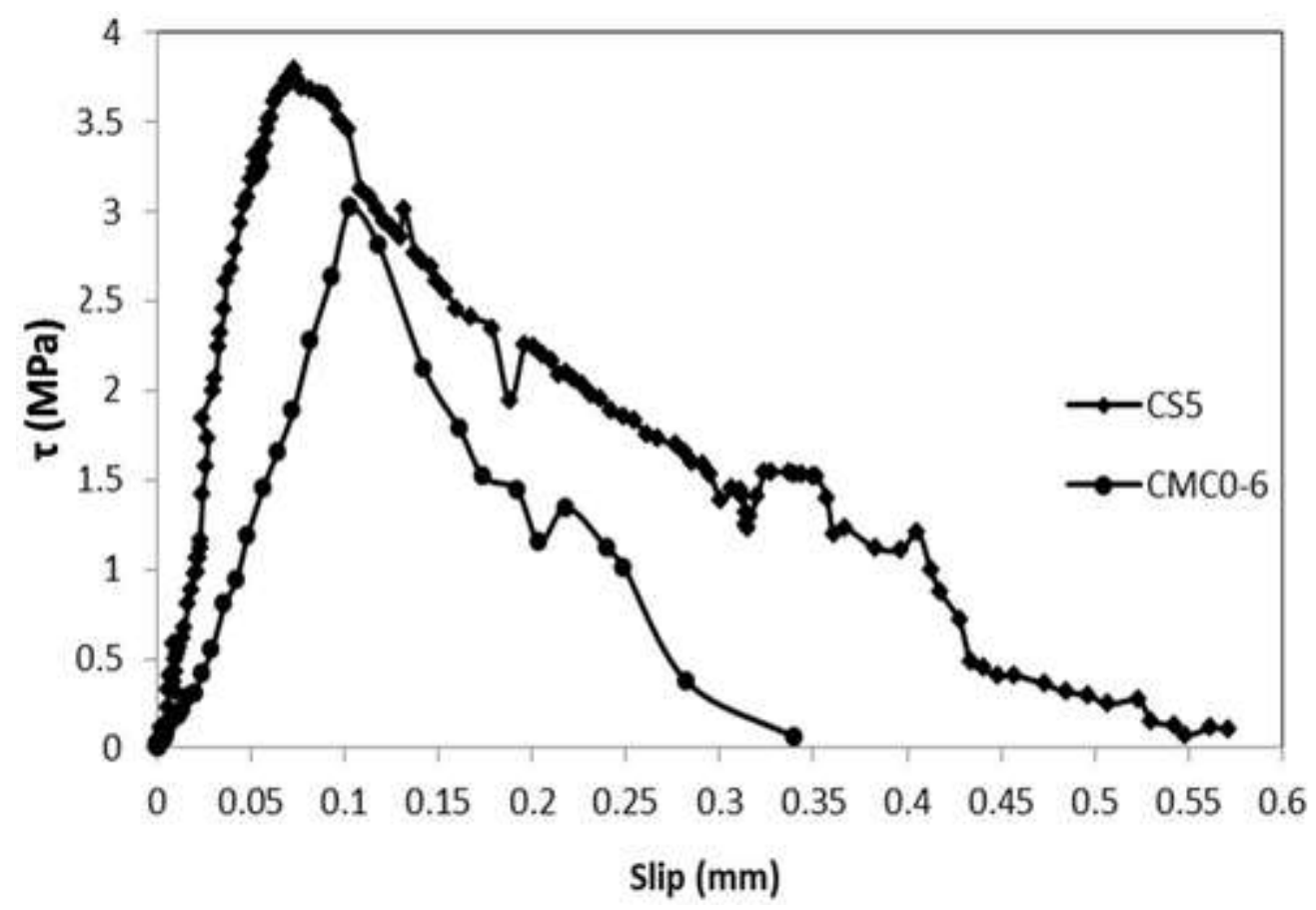

Figure 8. Bond-slip curves of beam specimen $\mathrm{CMCO}-6$ and single shear pull-out specimen CS5.

The maximum bond stress, $\tau_{\max }$, was calculated by using equations ( 1 ) and (2) and the experimentally obtained FRP strain values. The critical interfacial fracture energy, $G_{f}$, was obtained from the area under the bond-slip curve. The obtained values of maximum bond stresses and interfacial fracture energies for beam and single shear pull-out specimens are reported in Table 1 . The average of the maximum bond strength of the six beam specimens was $\tau_{\max }=3.23 \mathrm{MPa}$ with standard deviation $S T D=0.27 \mathrm{MPa}$, and the average of the interfacial fracture energy was $G_{f}=0.65 \mathrm{~N} / \mathrm{mm}$ with $\mathrm{STD}=0.14 \mathrm{~N} / \mathrm{mm}$. The average bond strength and fracture energy values of the five single shear pull-out tests were $\tau_{\max }=3.65 \mathrm{MPa}$ with STD $=0.34 \mathrm{MPa}$ and $G_{f}=1.41 \mathrm{~N} / \mathrm{mm}$ with $\mathrm{STD}=0.24 \mathrm{~N} / \mathrm{mm}$, respectively. It can be seen that both bond strength and fracture energy are smaller in the beam specimens. In order to find an explanation for the smaller values of the bond-slip behavior of the $\mathrm{FRP} / \mathrm{concrete}$ interface in beam specimens, the stress state of the interface in both test arrangements needed to be analyzed and compared. Numerical analyses were performed for this purpose as discussed in the following section.

\section{Table 1. Experimental values of $T \max$}


NOT THE PUBLISHED VERSION; this is the author's final, peer-reviewed manuscript. The published version may be accessed by following the link in the citation at the bottom of the page.

Table 1. Experimental values of $\tau_{\max }$ and $G_{f}$ obtained from beam test and single shear pull-out test.

\begin{tabular}{|c|c|c|c|c|c|}
\hline \multicolumn{3}{|l|}{ Beam test: } & \multicolumn{3}{|l|}{ Shear pull-out test } \\
\hline Specimen & $\tau_{\max }\left(M P_{a}\right)$ & $G_{r}(\mathrm{~N} / \mathrm{mm})$ & Specimen & $\tau_{\max }\left(M P_{a}\right)$ & $G_{r}(\mathrm{~N} / \mathrm{mm})$ \\
\hline $\mathrm{CMCO}_{-1}$ & 3.22 & 0.75 & CSI & 3.03 & 0.19 \\
\hline $\mathrm{CMCO}-2$ & 3.13 & 0.45 & & & \\
\hline $\mathrm{CMCO}_{3} 3$ & 2.98 & 0.59 & $\operatorname{cs} 2$ & 3.92 & 1.33 \\
\hline $\mathrm{CMCO}_{-4}$ & 3.75 & 0.69 & CS3 & 3.98 & 1.69 \\
\hline CMCO-5 & 3.25 & 0.85 & $\operatorname{cs} 4$ & 3.68 & 1.41 \\
\hline CMC0.6 & 3.02 & 0.54 & CS5 & 3.63 & 1.42 \\
\hline Average & 3.23 & 0.65 & Average & 3.65 & 1.41 \\
\hline Standard deviation & 0.27 & 0.14 & Standard deviation & 0.34 & 0.24 \\
\hline
\end{tabular}

\section{Finite Element Method}

The commercial software ABAQUS/standard 6.13 was used for the FE analysis. The plane stress 4-node bilinear 2D elements (CPS4R) were applied for the modelling of all materials. Figure 9 shows the typical FE meshes of the beam and the single shear pull-out specimens.

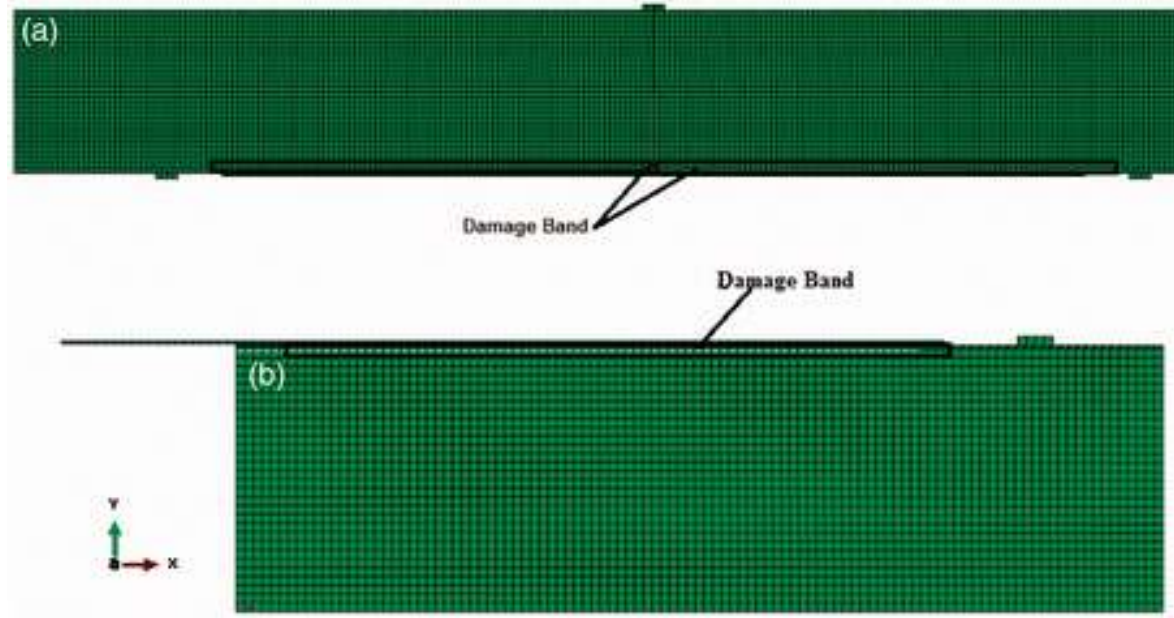

Figure 9. Typical finite element mesh: (a) beam specimen and (b) pull-out specimen.

It was observed in the experimental program that FRP debonding in both specimen types occurred in concrete cover a few millimeters away from the FRP/concrete interface and was essentially parallel to the interface. This phenomenon results from at least two factors: first, the penetration of adhesive into the (usually ground or otherwise abraded) cover concrete increases the toughness and

Journal of Reinforced Plastics and Composites, Vol 35, No. 5 (March 2016): pg. 375-386. DOI. This article is (C) SAGE Publications and permission has been granted for this version to appear in e-Publications@Marquette. SAGE Publications does not grant permission for this article to be further copied/distributed or hosted elsewhere without the express permission from SAGE Publications. 
strength of a thin layer of mortar adjacent to the interface and provides significant mechanical beyond in this region. $\frac{36}{\text { Secondly, the }}$ concrete substrate is the weakest component in the FRP/epoxy/concrete interface with a relatively small tensile strength. Based on this experimental observation, a thin damage band of $2 \mathrm{~mm}$ thicknesses was modeled along the interface as shown in Figure 9. Although a $25-\mathrm{mm}$ long precrack was made in one side of the notch in the beam specimens, the debonding did not start from the precrack tip, but from the diagonal crack tips at either sides of the notch as discussed previously in the experimental program. Therefore, the applied precrack did not work as the initiation point of the FRP debonding and it did not control to which side of the notch FRP debonding would occur. In the finite element analysis, in order to capture the diagonal cracking, the damage band was included along the whole FRP length for the beam specimens as shown in Figure 9(a).

To model the FRP/concrete interface, the cohesive zone method was applied. This method models the debonding behavior using the bond-slip curve of the interface. In this study, the constitutive response of the damage band was defined by a bilinear bond-slip relationship as shown in Figure 10 . According to this figure, the stressslip curve was assumed linear up to the bond strength and debonding was initiated. The postcracking behavior was presented by a descending linear damage law using the fracture energy value, $G_{f}$, that is equal to the area under the bond-slip curve. In the present numerical analysis, the fracture energy and bond strength were assumed equal to the experimentally obtained results presented in the previous section. 
NOT THE PUBLISHED VERSION; this is the author's final, peer-reviewed manuscript. The published version may be accessed by following the link in the citation at the bottom of the page.

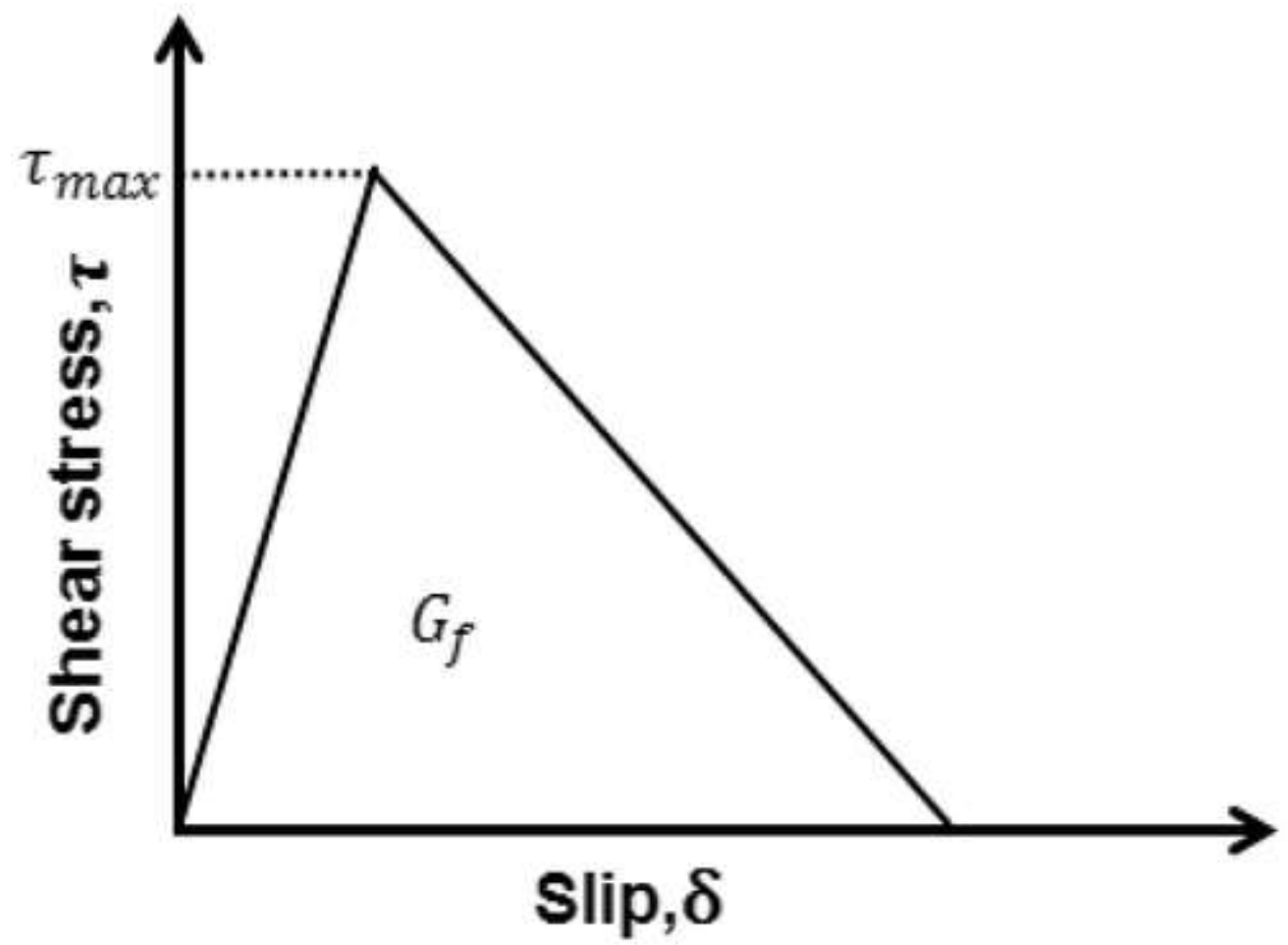

Figure 10. Bilinear bond-slip curve.

For the modeling of concrete, the concrete damaged plasticity model was applied. This method uses the maximum principal stress criterion for prediction of tension cracking in concrete. It assumes that a crack initiates if the maximum principal tensile stress reaches the tensile strength of the concrete. $\frac{37}{}$ The crack propagates in a direction perpendicular to the direction of the maximum principal tensile stress. The crack propagation criterion is the fracture energy of plain concrete, $G_{F}$, taken as equal to $0.12 \mathrm{~N} / \mathrm{mm}$ consistent with recommendations of Wittmann. $\frac{38}{\text { FRP }}$ and epoxy were modeled using a brittle cracking model. The thicknesses of FRP plate and epoxy are 1.5 and $1 \mathrm{~mm}$, respectively. A summary of the material properties in the FE analysis is presented in Table 2. 
NOT THE PUBLISHED VERSION; this is the author's final, peer-reviewed manuscript. The published version may be accessed by following the link in the citation at the bottom of the page.

Table 2. Material properties applied in FE analysis.

\begin{tabular}{|c|c|c|c|c|c|c|c|c|}
\hline \multirow{2}{*}{$\begin{array}{l}\text { Properties } \\
\text { Test }\end{array}$} & \multicolumn{2}{|c|}{ Concrete: } & \multicolumn{2}{|c|}{ Darrage band } & \multicolumn{2}{|l|}{ FRP } & \multicolumn{2}{|l|}{ Epoxy } \\
\hline & Beam & Shear & Beam. & Shear & Beam & Shear & Beam & Shear \\
\hline Modulus of elasticity. $E\left(G P_{2}\right)$ & 23.62 & 30.5 & 23.62 & 30.5 & 155 & 155 & 4.48 & 1.2 \\
\hline Tensile strength, ff (MPa) & 3.16 & 3.58 & 3.16 & 3.58 & 2800 & 2800 & 24.8 & 22.7 \\
\hline Compressive strength, $f_{c}(\mathrm{MPa})$ & 30.37 & 32.90 & - & - & - & - & - & - \\
\hline Shear strength, $T_{\max }(\mathrm{MPa})$ & - & - & 3.23 & 3.65 & - & - & - & - \\
\hline Fracture energy, $G_{\text {f }}(\mathrm{N} / \mathrm{mm})$ & 0.12 & 0.12 & 0.65 & 1.41 & - & - & - & - \\
\hline Poisson's ratio & 0.2 & 0.2 & 0.2 & 0.2 & 0.25 & 0.25 & 0.3 & 0.3 \\
\hline
\end{tabular}

\section{Numerical Results}

Figure 11 shows the FE-predicted FRP debonding failures. In the single shear pull-out test specimens (Figure 11(a)), the debonding started at the tip of precrack and propagated along the FRP/concrete interface to the end of the plate in a manner similar to the experimental observations (Figure 7). In the beam specimens shown in Figure 11(b), the applied method is able to predict the cracking at the top of the notch and also the diagonal crack about $25 \mathrm{~mm}$ from the notch. After the diagonal crack formation, the FRP debonding started at the tip of the diagonal cracks parallel to the interface. In the FE analysis, when the strain energy in the element at the top of the notch (Figure 11(b)) reached the critical fracture energy of concrete, this element was no longer able to transfer stress. At this stage, the behavior of concrete and the whole model became unstable.

Therefore, the analysis was terminated and this stage was considered to be the final failure step of the FE analysis. Because of the symmetry of the FE model, the diagonal crack and partial FRP debonding were seen at both sides of the notch. The FE-predicted debonding processes of the beam specimens are in a very good agreement with the experimental observations (Figure $5(\mathrm{a})-(\underline{\mathrm{d}})$ ). 
NOT THE PUBLISHED VERSION; this is the author's final, peer-reviewed manuscript. The published version may be accessed by following the link in the citation at the bottom of the page.

(a)

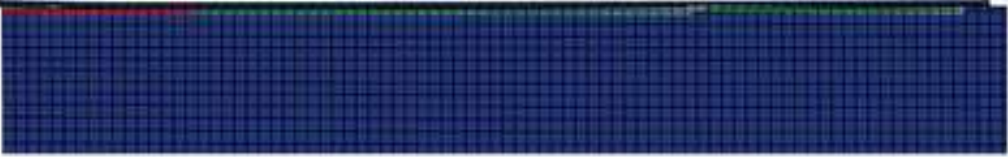

(b)

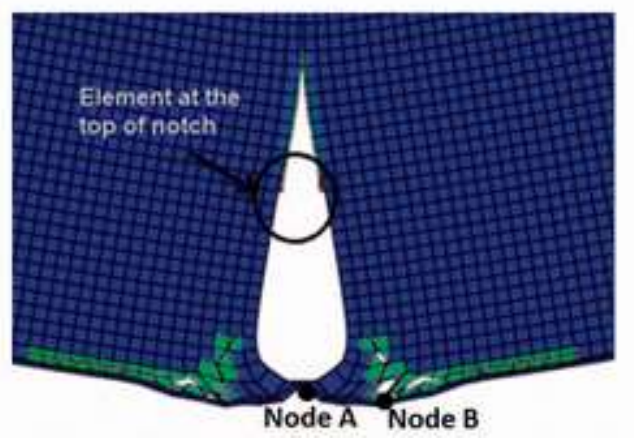

Figure 11. FRP debonding failure predicted by FE analysis: (a) single shear pull-out test and (b) beam test.

Figure 12 compares the load vs displacement curves of the numerical and experimental results. Finite element method is able to predict the trend of behavior and also the maximum bearing load of the single shear pull-out test and the beam test with error of 2.2 and $2.5 \%$, respectively.

Journal of Reinforced Plastics and Composites, Vol 35, No. 5 (March 2016): pg. 375-386. DOI. This article is (C) SAGE Publications and permission has been granted for this version to appear in e-Publications@Marquette. SAGE Publications does not grant permission for this article to be further copied/distributed or hosted elsewhere without the express permission from SAGE Publications. 

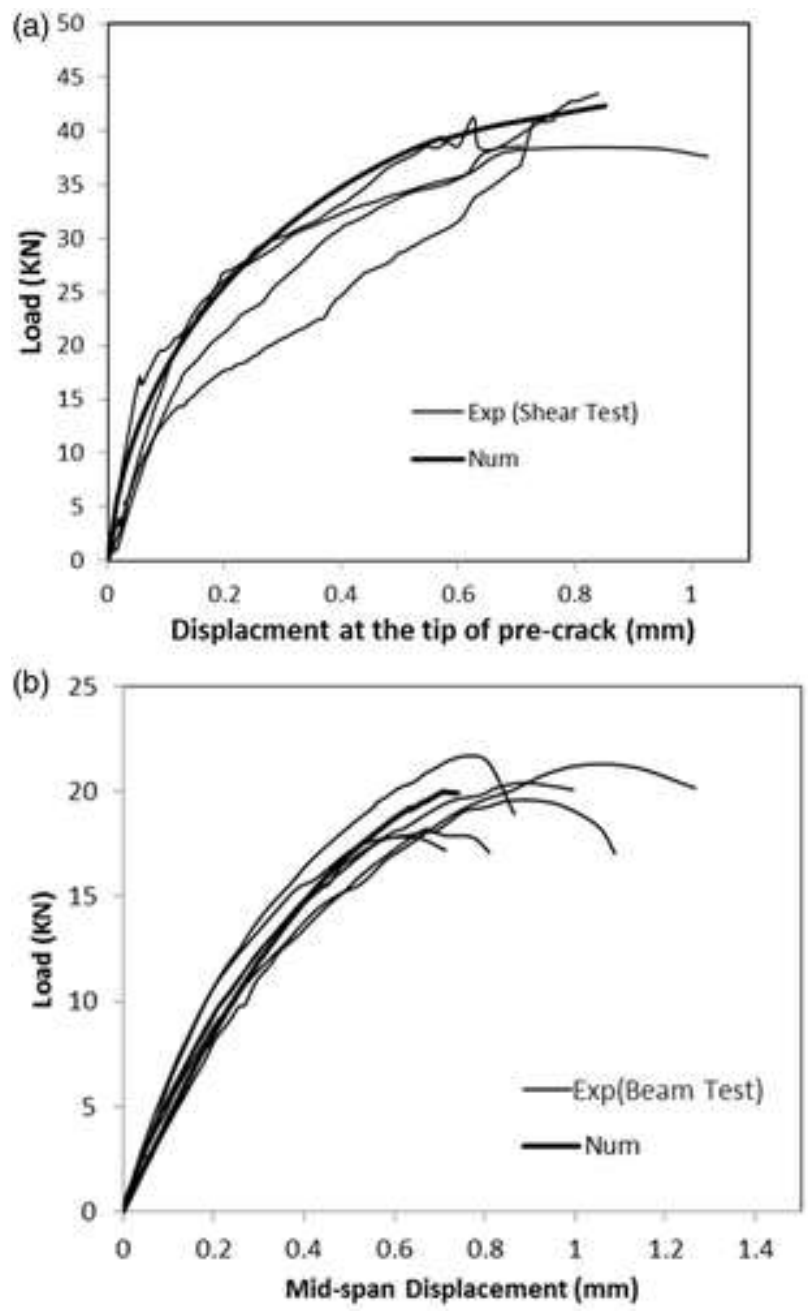

Figure 12. Load vs. displacement curves obtained by experimental tests and numerical analysis: (a) single shear pull-out specimens and (b) beam specimens.

\section{Discussion}

It can be seen in Figure 11(b) that the vertical displacement of FRP element below the notch (node $A$ ) is less than the displacement of the element at the tip of diagonal crack (node B). Figure 13 presents the vertical displacement of node $B$ relative to that of node $A$ indicating that node $B$ deflects a greater amount and shows that this relative deflection is proportional to the applied load. This deflection behavior is due to a local moment created by the tension force in the FRP plate by the vertical downward displacement of the concrete, and causes a different stress state at the FRP/concrete interface in the beam specimens from that in the single shear pull-out specimens. Figure 14

Journal of Reinforced Plastics and Composites, Vol 35, No. 5 (March 2016): pg. 375-386. DOI. This article is C SAGE Publications and permission has been granted for this version to appear in e-Publications@ Marquette. SAGE Publications does not grant permission for this article to be further copied/distributed or hosted elsewhere without the express permission from SAGE Publications. 
shows the numerically obtained stress state of an element at the FRP/concrete interface in the beam and the single shear pull-out specimens. In the beam specimens, the concrete element attached to the FRP/concrete interface is under shear stress, $\tau$, and longitudinal tension stress, $\sigma_{X}>0$. The magnitude of longitudinal tension stress is larger than shear stress, $\sigma_{x}>\tau$. In the single shear pull-out specimens, the concrete element at the tip of the precrack is under shear stress, $\tau$, and longitudinal compression stress, $\sigma_{x}<0$, while the absolute value of $\sigma_{X}$ is smaller than shear stress, $\left|\sigma_{X}\right|<|\tau|$.

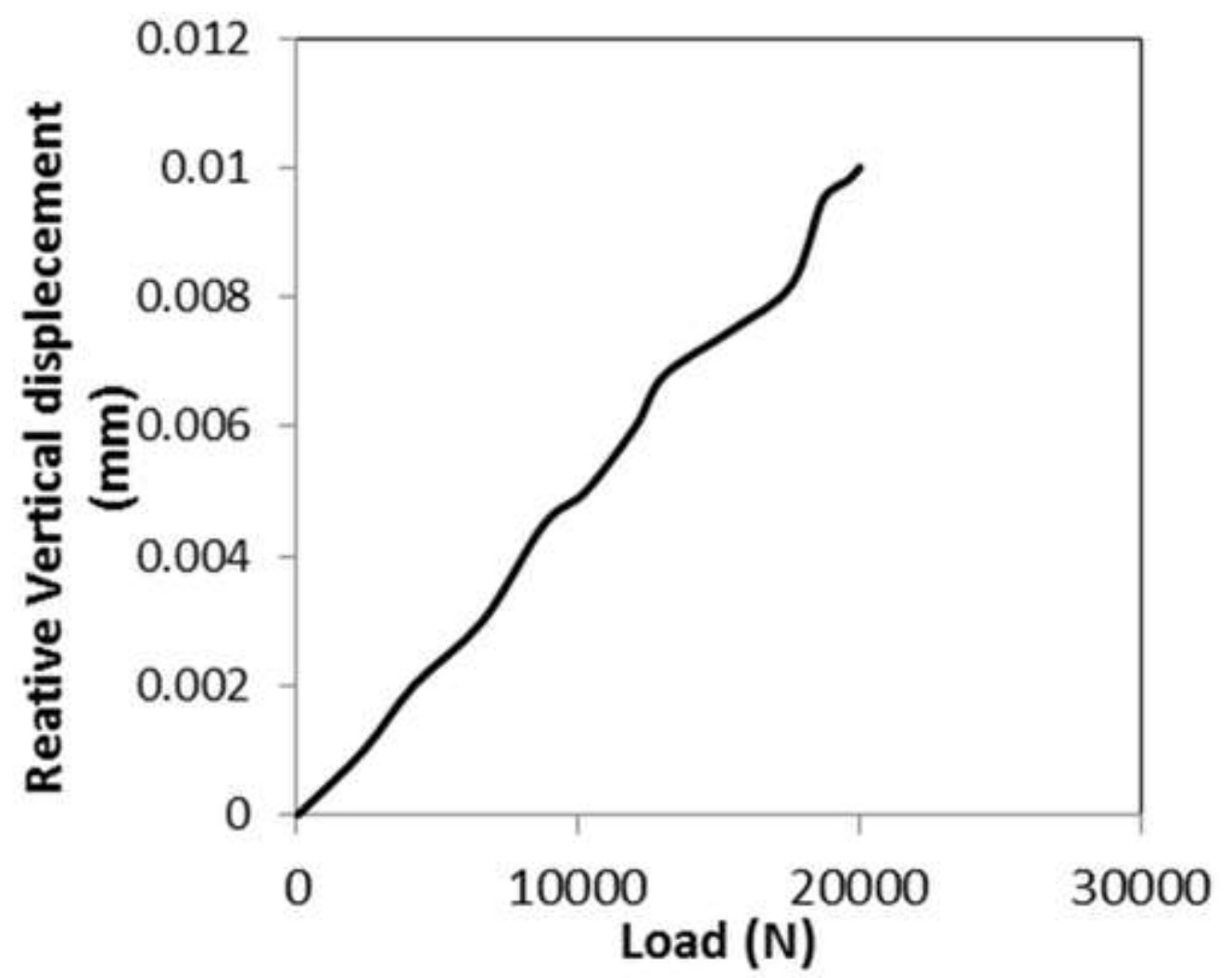

Figure 13. Relative vertical displacement of node $B$ to node $A$.

Journal of Reinforced Plastics and Composites, Vol 35, No. 5 (March 2016): pg. 375-386. DOI. This article is (C) SAGE Publications and permission has been granted for this version to appear in e-Publications@Marquette. SAGE Publications does not grant permission for this article to be further copied/distributed or hosted elsewhere without the express permission from SAGE Publications. 
NOT THE PUBLISHED VERSION; this is the author's final, peer-reviewed manuscript. The published version may be accessed by following the link in the citation at the bottom of the page.

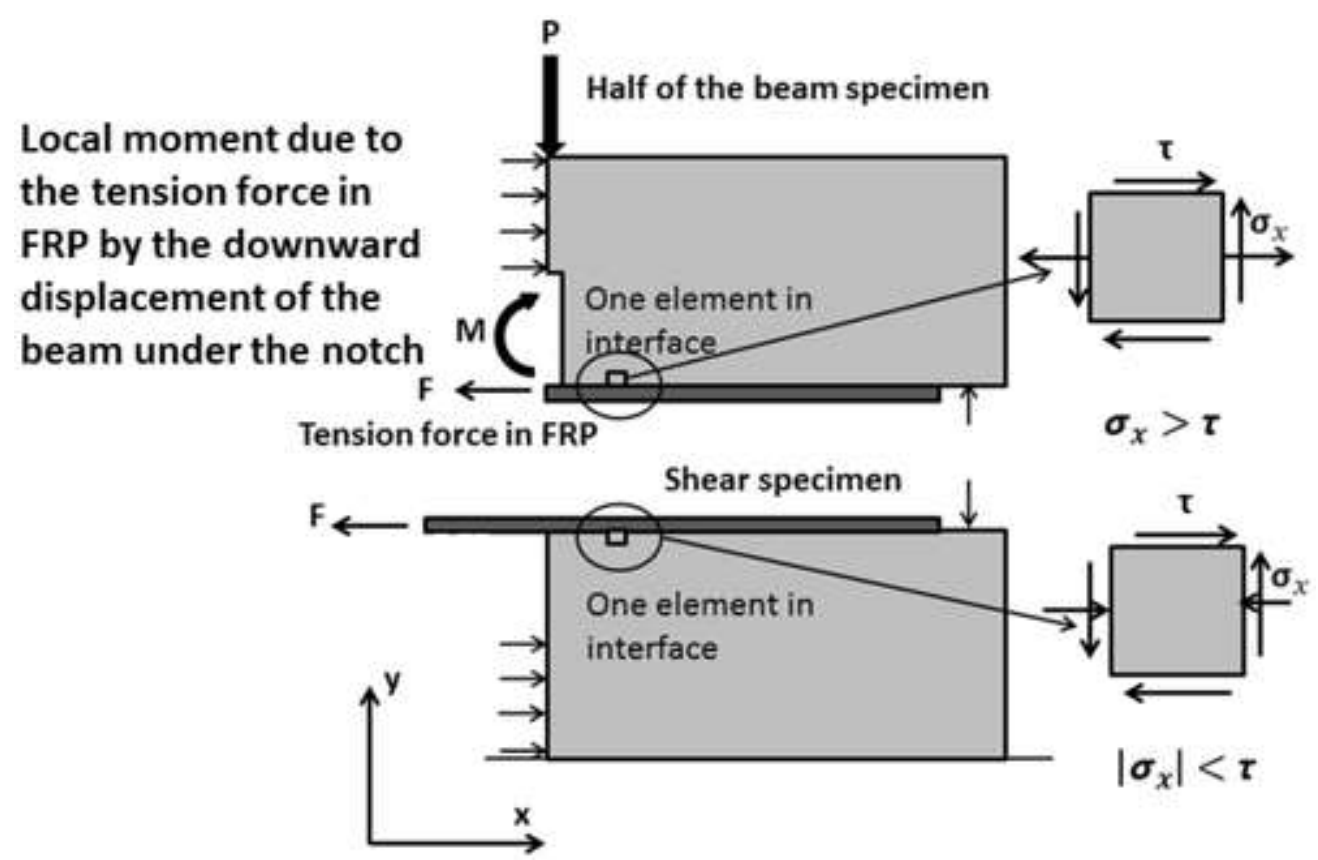

Figure 14. Comparison of the stress states at the FRP/concrete interface between beam and single shear pull-out beam specimens.

Since the FRP debonding failure occurs in the concrete close to the FRP/concrete interface, it is reasonable to express the bond strength as a function of concrete strength. Thus, when the maximum principle tension stress in the element at the tip of precrack reaches the concrete tensile strength, $f_{t}$ a crack initiates in the element. Based on this assumption and assuming that $\sigma y$ is negligible; the crack initiation criterion can be defined as

$$
f_{t}=\frac{\sigma_{x, \max }}{2}+\sqrt{\left(\frac{\sigma_{x, \max }}{2}\right)^{2}+\tau_{\max }^{2}}
$$

Therefore, the bond strength, $\tau_{\max }$, as a function of concrete tensile strength and the maximum normal stress component in the element can be expressed as:

$$
\tau_{\max }=\sqrt{\left(f_{t}-\frac{\sigma_{x, \max }}{2}\right)^{2}-\left(\frac{\sigma_{x, \max }}{2}\right)^{2}}
$$

Equation (4) shows that the bond strength is greater in the presence of compression stress ( $\sigma_{x}<0$; i.e., the pull-out test) than in the

Journal of Reinforced Plastics and Composites, Vol 35, No. 5 (March 2016): pg. 375-386. DOI. This article is (C) SAGE Publications and permission has been granted for this version to appear in e-Publications@Marquette. SAGE Publications does not grant permission for this article to be further copied/distributed or hosted elsewhere without the express permission from SAGE Publications. 
presence of tensile stress ( $\sigma_{x}>0$; i.e., the beam test). Therefore, the bond strength determined from the FRP-strengthened beams is less than the bond strength determined from the single shear pull-out specimens, and the single shear pull-out test result does not represent the bond strength of the FRP/concrete interface in the FRPstrengthened concrete beams.

By comparing the experimental bond-slip curves (Figure 8), it can be seen that the slips at the tip of the diagonal crack close to the notch (i.e., the mid-span flexural/shear crack) in the beams are smaller than the slips of the FRP plate at the tip of the precrack in the pull-out specimens. The slip is largely affected by the modulus of the adhesive layer which is smaller by a factor of 3.7 in the single shear pull-out specimens (Table 2). Therefore, the slip of the shear specimens is greater than that of the beams specimens. Since the bond strength of the beam specimens is also smaller than that of the pull-out specimens, the interfacial fracture energy of the bond (the area under the bond-slip curve) in the beams is less than that in the pull-out specimens. However, the FE analyses show that the fracture energy value of the bond-slip relationship does not control the final failure of the beam specimens. As explained in the section of finite element analysis, the final failure of the beam occurs when the fracture energy in the element at the top of the notch (Figure 11(b)) meets the critical fracture energy of the plain concrete. Therefore, the plain concrete fracture energy, which is considerable less than the $\mathrm{FRP} /$ concrete interfacial fracture energy, plays the key role for the beam failure.

\section{Conclusions}

In the present study, the bond-slip relationship of the $\mathrm{FRP} /$ concrete interface was obtained separately by beam and single shear pull-out tests for the comparison. In the beam specimens, a concrete wedge attached to the FRP after debonding failure was observed in all cases. This phenomenon indicates that the initiation of FRP debonding was due to a diagonal crack formation close to the major flexural/shear crack inside the concrete. 
FE analysis was performed for the FRP-strengthened concrete beams and the single shear pull-out test specimens by using the bond-slip relations obtained from the experimental tests. The applied numerical method is able to predict the load vs. deflection relations and the debonding processes, which are compatible with the experimental observations. According to the numerical analyses, the diagonal crack in concrete beam is due to a local moment at the tip of the notch.

The local moment at the tip of the notch causes the different stress state at the FRP/concrete interface and different behavior of beam specimens from those of the single shear pull-out specimens. Experimental observations and numerical analyses show that the bond strength and critical fracture energy in the beam specimens are smaller than those in the single shear pull-out specimens even when the same boundary conditions are used. Therefore, the single shear pull-out test results cannot be directly used for the analysis of IC debonding failure in the FRP strengthened concrete beams. The beam test presented in this study can better represent the in situ conditions of the FRP-strengthened concrete beams and a standard beam test method should be developed in order to provide more reliable design parameters to designers.

\section{Declaration of Conflicting Interests}

The author(s) declared no potential conflicts of interest with respect to the research, authorship, and/or publication of this article.

\section{Funding}

The author(s) disclosed receipt of the following financial support for the research, authorship, and/or publication of this article: This study was supported by the financial aid for graduate student research assistant from Marquette University Graduate School.

\section{References}

1 Teng JG, Smith ST, Yao J, . Intermediate crack-induced debonding in RC beams and slabs. Constr Build Mater 2003; 17: 447-462. 
2 Abdelouahed T. Improved theoretical solution for interfacial stresses in concrete beams strengthened with FRP plate. Int J Solids Struct 2006; 43: 4154-4174.

3 Tounsi A, Hassaine Daouadji T, Benyoucef S, . Interfacial stresses in FRPplated RC beams: effect of adhered shear deformations. Int J Adhes Adhes 2009; 29: 343-351.

4 Yao J, Teng JG. Plate end debonding in FRP-plated RC beams-I: experiments. Eng Struct 2007; 29: 2457-2471.

5 Teng JG, Yao J. Plate end debonding in FRP-plated RC beams-II: strength model. Eng Struct 2007; 29: 2472-2486.

6 Chen J, Teng J. Anchorage strength models for FRP and steel plates bonded to concrete. J Struct Eng 2001; 127: 784-791.

7 Chen J, Yang Z, Holt G. FRP or steel plate-to-concrete bonded joints: effect of test methods on experimental bond strength. Steel Compos Struct 2001; 1: 231-244.

8 Brosens $\mathrm{K}$ and Gemert D. Anchorage stresses between concrete and carbon fiber reinforced laminates. In: Non-metallic (FRP) reinforcement for concrete structures, proceedings of third international symposium, 1997, pp. 71-278.

9 Yoshizawa $\mathrm{H}$, Wu Z, Yuan H, . Study on FRP-concrete interface bond performance. Trans Jpn Soc Civil Eng 2000; 662: 105-119.

10. Nakaba K, Kanakubo T, Furuta T, . Bond behavior between fiberreinforced polymer laminates and concrete. ACI Struct J 2001; 98: 359-367.

11 Serbescu A, Guadagnini M, Pilakoutas K. Standardized double-shear test for determining bond of FRP to concrete and corresponding model development. Compos B: Eng 2013; 55: 277-297.

12 Chajes MJ, Finch WW, Januszka TF, . Bond and force transfer of composite material plates bonded to concrete. ACI Struct J 1996; 93: 208-217.

13 Taljsten B. Defining anchor lengths of steel and CFRP plates bonded to concrete. Int J Adhes Adhes 1997; 17: 319-327.

14 Bizindavyi L, Neale KW. Transfer lengths and bond strengths for composites bonded to concrete. J Compos Constr 1999; 3: 153-160.

15 Leung CKY, Tung WK. Three-parameter model for debonding of FRP plate from concrete substrate. J Eng Mech 2006; 132: 509-518.

16 Mazzotti C, Savoia M, Ferracuti B. An experimental study on delamination of FRP plates bonded to concrete. Constr Build Mater 2008; 22: 1409-1421.

17. Fukuzawa K, Numao T, Wu Z, et al. Critical strain energy release rate of interface debonding between carbon fiber sheet and mortar. In: 
NOT THE PUBLISHED VERSION; this is the author's final, peer-reviewed manuscript. The published version may be accessed by following the link in the citation at the bottom of the page.

Non-metallic (FRP) reinforcement for concrete structures, proceedings of third international symposium 1997, vol. 1, pp. 295301.

18 Benjeddou O, Ouezdou MB, Bedday A. Damaged RC beams repaired by bonding of CFRP laminates. Constr Build Mater 2007; 21: 13011310.

19 Gartner AL, Douglas EP, Dolan CW, . Small beam bond test method for CFRP composites applied to concrete. ASCE J Compos Constr 2011; 15: $52-61$.

20 Harries K, Hamilton HR, Kasan J, et al. Development of standard bond capacity test for FRP bonded to concrete. In: 6th international conference on fiber reinforced polymer (FRP) composites in civil engineering (CICE), Rome, Italy, 2012.

21. Davalos JF, Madabhusi-Raman P, Qiao P. Characterization of mode-I fracture of hybrid material interface bonds by contoured DCB specimens. Eng Fract Mech 1997; 58: 173-192.

22 Wan B, Petrou MF, Harries KA. Effect of the presence of water on the durability of bond between CFRP and concrete. J Reinf Plast Compos 2006; 25: 875-890.

23 Ouyang Z, Wan B. Experimental and numerical study of moisture effects on thebond fracture energy of FRP/concrete joints. J Reinf Plast Compos 2008; 27: 205-223.

24 Karbhari VM, Engineer M. Investigation of bond between concrete and composites: use of a peel test. J Reinf Plast Compos 1996; 15: 208227.

25 Wan B, Sutton MA, Petrou MF, . Investigation of bond between fiber reinforced polymer and concrete undergoing global mixed mode I/II loading. J Eng Mech 2004; 130: 1467-1475.

26 Guo T, Song Y, Chen W, . Experimental study on bond behavior between SMPM and concrete using dual-beam speckle interferometry. J Reinf Plast Compos 2011; 30: 671-684.

27 Dai J, Ueda T, Sato Y. Development of the nonlinear bond stress-slip model of fiber reinforced plastics sheet-concrete interface with a simple methods. J Compos Constr 2005; 9: 52-62.

28 Zhou YW, Wu YF, Yun Y. Analytical identification of the bond-slip relationship at FRP-concrete interfaces for adhesively-bonded joints. Composites Part B 2010; 41: 423-433.

29 Shams SS, El-Hajjar RF. overlay patch repair of scratch damage in carbon fiber/epoxy laminated composites. Compos A: Appl Sci Manuf 2013; 49: $148-156$.

Journal of Reinforced Plastics and Composites, Vol 35, No. 5 (March 2016): pg. 375-386. DOI. This article is (C) SAGE Publications and permission has been granted for this version to appear in e-Publications@Marquette. SAGE Publications does not grant permission for this article to be further copied/distributed or hosted elsewhere without the express permission from SAGE Publications. 
NOT THE PUBLISHED VERSION; this is the author's final, peer-reviewed manuscript. The published version may be accessed by following the link in the citation at the bottom of the page.

30 Shams SS, El-Hajjar RF. Adhesive repair for surface gouges and cracks in continues carbon fiber/epoxy laminated composites. Joining Compos Adhes Theory Appl 2015; Chapter 8: 173-195.

31 Mohammadi T, Wan B, Dai JG, . Prediction of load capacity variation in FRP bonded concrete specimens using brownian motion. Math Probl Eng 2015; 2015: 632912 (9pp.)-632912 (9pp.).

32 D'Antino T, Pellegrino C. Bond between FRP composites and concrete: assessment of design procedures and analytical models. Composites Part B 2014; 60: 440-456.

33 Mohammadi T, Wan B. Sensitivity analysis of stress state and bond strength of FRP/concrete interface to boundary conditions in single shear pull-out test. Adv Mech Eng 2015; 2015: 585419-585419.

${ }^{34}$ FIB Task Group 9.3. Externally bonded FRP reinforcement for $R C$ structures. Technical Report, Fib Bulletin 14, 2001. CEB-FIP: Lausanne, Switzerland.

35 Mohammadi T. Failure mechanisms and key parameters of FRP debonding from cracked concrete beams. PhD Dissertation, Marquette University, Milwaukee, WI, 2014.

36 Coronado C, Lope M. Experimental characterization of concrete-epoxy interfaces. J Mater Civil Eng 2008; 20: 303-312.

37 Mohammadi T, Wan B, Dai J. Modeling of CFRP-concrete interface subjected to coupled pull-out and push-off actions. ACI Spec Publ 2011; 275: 1-18.

38 Wittmann FH. Crack formation and fracture energy of normal and high strength concrete. Sadhana (India) 2002; 27: 413-423.

Journal of Reinforced Plastics and Composites, Vol 35, No. 5 (March 2016): pg. 375-386. DOI. This article is (C) SAGE Publications and permission has been granted for this version to appear in e-Publications@Marquette. SAGE Publications does not grant permission for this article to be further copied/distributed or hosted elsewhere without the express permission from SAGE Publications. 